International Journal of Engineering \& Technology, 7 [2.29] [2018] 660-666
International Journal of Engineering \& Technology
SPC
Website: www.sciencepubco.com/index.php/IJET
Research paper

\title{
Health Political Communication After the Issuance of Presidential Regulation No. 18 Year 2016: a Case Study in RSUD Kabupaten Karawang
}

\author{
Siti Nursanti ${ }^{*}$, Susanne Dida ${ }^{2}$, Mien Hidayat ${ }^{3}$, Irvan Afriandi ${ }^{4}$ \\ ${ }^{1}$ Singaperbangsa University \\ ${ }^{2}$ Padjadjaran University \\ ${ }^{3}$ Padjadjaran University \\ ${ }^{4}$ Padjadjaran University \\ *Corresponding Author E-Mail: Sitinursanti@Yahoo.Com, Siti.Nursanti@Staff.Unsika.Ac.Id
}

\begin{abstract}
Amendment to Government Regulation number 18 of 2016 begins with the issuance of Law Number 23 Year 2014 on Regional Instrument Organization to replace Law no. 32 year 2014. In this study, researchers used qualitative methods with Case Study approach, the researchers considered this method is very appropriate that best describe the phenomenon in political communication research related to post-implementation of Government Regulation No. 18 of 2016. Ability to provide rich portraits which is the main benefit of case studies. The research reader should be made to feel as if you were there with you in your research, see what you see, summarize what you have concluded. This research was conducted in Public Hospital Karawang regency. In this study researchers found that: 1. Hospital changed the status that was originally Regional Technical Institute into Limited Service Unit Region under the health service 2 . The Director is a physician or dentist whose functional status is then given an additional duty to become the Director of the Hospital 3 . The Health Office is a member of the hospital supervisory board as well as the operational operator of the hospital has resulted an overlapping coordination in organizational communication
\end{abstract}

Keywords: Political Communication; Health Communication; Health Political Communication; Communication Organization

\section{Introduction}

PP No. 18 year 2016 is the latest government regulation governing local governance, the Government Regulation is derived from Law number 23 year 2014. Article 43 in the government regulation No. 18 year 2016 mentioned that the Regional Hospital as a functioning Functional organization unit Professionally. Language is not significantly different because the Regional Hospital is a service unit, only structurally changed because it is no longer implemented by structural officers of duties and functions of the organization in the Hospital performed purely by functional employees who get the additional task of doing structural work.

Law 32 Year 2004 on Regional Government is a change from Law Number 22 year 1999 which is the forerunner of the era of Decentralization or Regional Autonomy after the collapse of the New Order through a series of historical reforms in 1998. Article 120 Paragraph [2] Law Number 32 Year 2004 It is stated that the regional apparatus of the Regency / City consists of the Regional Secretariat, the Secretariat of the Regional People's Legislative Assembly, the Regional Office, the Regional Technical Institute, the Sub-District and the Sub-District. In law device derived from Law Number 32 year 2004 namely Government Regulation No. 41 year 2007 on Regional Government Organization in Article 8 and Article 15 it is clearly stated that the Regional Technical Institute may take the form of Agency, Office and Hospital so that it can be concluded the position of Regional Hospital is as Regional Technical Institute led by a director and directly responsible to the
Head of Region through the Regional Secretary. The status of legal entities and institutions is adopted by local hospitals up to now.

However, in Law Number 23 year 2014 concerning Regional Government which is a change of Law Number 32 Year 2004 explicitly in Article 209 Paragraph [2] which reads that the Regional Devices of regencies / municipalities consist of: Regional Secretariat, Secretariat of DPRD, Inspectorate, And District. Already disappears Regional Technical Institute as the institutional holding of local hospitals. At the time I wrote about the possibility of RSD under Health Department [May 2015] and then there is no derivative law. Only I heard the rumor that RSD will be under the Health Service in the form of Technical

Government Regulation [PP] No. 18/1986 on the Regional Tool in Article 43 which substantially states that there is a Technical Implementing Unit of District / Municipal Service in the health sector in the form of a district hospital and a community health center as a functional organizational unit and service unit Who work professionally. This article analyze the disappearance of the Regional Hospital entity as an institution under the distric mayor and turned into a unit under the Head of the District Health Office. The regional hospital as a functional organization unit that works professionally runs its organization under the health service, so that no structural officials are placed in the Regional Hospital. In his work the Regional Hospital is responsible to the local Public Health Service and led by a doctor appointed by the head of health department. The task of leading the Regional Hospital for a doc- 
tor is only an additional task while the main task is to keep doing professional service to the community.

The financial management of the Hospital also has its own rules that can only be done by the Hospital through the regulations contained in the Government Regulation concerning the financial management guidelines of regional public service agencies. With the use of rules of financial management guidance of public service agencies, hospitals are allowed to ignore regulations on procurement of goods and services contained in Presidential Regulation number 54 of 2010 .

The hospital is a unique and very specific organization as an agency. Not only the profession of doctors are there and working in the hospital, there are many other professions who work in hospitals such as pharmacists, nurse analysts and others. It is not easy for a Director to do homework that has to be done up to now, among others, taking care of public health insurance, accrediting services and making hospitals as a comfortable and suitable place for health education.

The development of hospitals experienced a huge leap, in the global era and the publication of the Public Hospital Open Act in the guise of not only doing excellent service but becoming an open institution and able to compete with other alternative medicine. Clear management is required for hospitals to compete in the global era. Currently so many laws and regulations issued by the new president of the government resulted in turbulence services in hospitals. The progress of hospital development is currently undergoing major changes where hospitals are in a global and competitive environment. Hospitals as health facilities are required to always maintain their quality by providing services in accordance with the expectations of the community as the recipient of services can feel satisfied [1]

Professional management means implementing management in a way that can be accountable and implemented by trained people and as well as having accountable ability in order to provide the best service to the community. Maintaining the quality of service is the main thing that must be done by the whole range of hospital management. Effort satisfaction of a performance and patient satisfaction on hospital service require relationship which is intertwined among related organizational unit. However, the interconnected process refers to job satisfaction on the members of the organization. A company needs a leader who able to assist the coordination of the organization members due to the success or failure of an organization is determined by the leader. Government Regulation No. 18 year 2016 mentions that the director of the hospital is a functional physician who performs additional duties as a director.

Until now, leadership in an organization considered as interesting issue to investigate, the background of the leader of his leadership style can also affect how the leader runs the organization. The division of top-tier power always has a special magnet within an organization, various interests lie behind the power struggle. [2] state that the quality of the leader is often considered the most important factor that determines the success and failure of the organization. Moreover, [3] also states that leaders have a major influence on organizational success. [4] states that leadership is a key element in organizational effectiveness.

The shift of political structure in Indonesia after the New Order regime marked as a stepping stone for the growth of democracy in this country. The birth of new parties and changes in the electoral system bring a new dynamic of national politics. It is interesting to note that since 2005 a year after it was established at the national level the provinces and districts of Indonesia have made the first direct election to elect the governors, mayors, and bupatis. Law number 32 year 2004 which regulates the implementation of direct elections as a form of decentralization or manifestation of regional autonomy that distinguishes the two regimes of the new order and the reform era.

After the direct election of regional head elections, electoral politics in Indonesia has undergone much change in terms of implementation, election format and recruitment of candidates in local elections or legislative elections. The change of this system is an implementation of the amendment of the 1945 Constitution with the aim to maturely democratize more substantively and not procedurally.

The health sector is one of the sectors that has its own magnet in Indonesian political stretch. Fiscal decentralization in the health sector is the experience of the years 2000-2007 on the difficulties of the central government in understanding the impact of financial decentralization in the early period of decentralization. When there is a transfer of budget allocations to the regions through general allocation funds, what happens is the failure of the health sector to obtain funds in the region. This failure is responded by the central government by providing a large deconcentration fund. As a result, the situation resembles the decentralization of health budget allocation system around 2004-2005. However, with limited financial capacity of the central government and technical difficulties in the distribution of deconcentrated funds, central government funding in 2006-2007 and early 2008 experienced great difficulties. [5]

The mandate of the Regional Autonomy Law deligate the authority to regions in the management of regional apparatus organizations. The role of the region is considered necessary considering the vastness of Indonesia. History has noted that in the late 1970s, Indonesia decentralized health was not accompanied by fiscal decentralization. As a result there is no transfer of authority from the central government to the regions. This section examines whether the fiscal decentralization policy is working, and seeks to understand the prospects for health development in the decentralization era [5]

The year of 1999 was declared a big bang period of the health world, where so many health sector policies were not followed by good technical issues that became a year of confusion for the implementation of health sector in Indonesia. Health decentralization occurred in the period of 2000-2007 with various problems as follows

Fiscal decentralization is perceived to be a failure because so far financial planning and financing of the health sector are more widely shared through the central government so the distribution is irregular between small and large areas.

Health insurance that uses Askes kin its application fails because of ignorance of local government against technical guidance and guidance of its implementation.

Surveillance in 2004 the government is seen as confusing about whether to use a system of centralization or decentralization.

Trisnanto's work said that there has been a fiscal capacity in which the ability of the community will be low in the post-health care. The central government focuses on the patient's healing program after which the local government must allocate funds for the post-health program. The local government during this time approached the need basic approach where the local government feels that they have no health sector. This is reflected in the procurement of budgets in the health sector that can be seen from the observation of the budget used so far. The health sector is too strong for political atmosphere to take into account of technical rationality compared with political pressure.

There are several important things in the concept of good governance coined by the United Nations Development Program, among others: community participation, transparency, accountability, and putting the rule of law. In the context of good governance, the government's role in the health sector has three aspects, namely: regulator, donor and implementer of activities. [6]

The role of the government as a source of financing is undertaken by central and local governments. The financing of the Health Sector from the Central Government is derived from the State Revenue and Expenditure Budget which is divided into Deconcentration Funds and Special Allocation Funds, Deconcentration Funds that fund the Health sector at the central level and at the provincial level, while the Special Allocation Fund is the Budget of Revenue and Expenditure of the country that finances the Health sector at the Regency / City level. While the health sector financing by the Regional Government [Provincial and District / City] originated from the General Allocation Fund. 
The role of the Government as a regulator and health service policy providers can be done by the Ministry of Health in the Central Government through the National Health System at the Indonesian Level and the Regional Health System at the Provincial and District / City levels. Another example of the Policy / Regulation Determination by the Ministry of Health with the stipulation of Minimum Service Standards containing Health Development Indicators and by regions shall be made of Minimum Service Standards according to the needs and conditions of their respective regions.

The role of government as executor is done through Government Health Service Facilities in the form of central and local hospitals, and Puskesmas. Public health services are not only carried out by the government but also implemented by the private sector. Therefore, the Government as the implementer needs to create a good Health Service Management system.

In support of the three roles of government mentioned above are needed some things, namely:

Political commitment for the development of health services, especially for local government at the Provincial and District level of the city. The health sector for local government is still less priority compared to other sectors.

Pro-poor approach

Balancing the role of government, private business institutions and non-governmental organizations in health services

Deal with market failures, for example, the government should finance the poor who cannot afford health services

Management of user-oriented health care institutions

Widespread participation of communities and business entities in decision-making, health sector reform, and the development of health systems

Combating illegal practices in Health services, including corruption. Healthy and responsive health service financing

Decentralization of Services

The decentralization of health that began in the year of 2000 began with the existence of the Regional Autonomy Law. The Center divides its role in performing as public health administrator with local government. In 2001 to 2004 the use of hospital facilities by the public increased which is seen from the escalation in hospital occupancy rate reached 100 percent. Many people are increasingly aware of using health facilities provided by the government.

The problem arises when the local government can not translate the criteria of the poor who become the reference in the community service activities that use public health insurance sourced from the government. The problem did not stop there, many hospital managers in this case the director who have problems in financial matter due to frequently late of health insurance parties in doing service. The purchase of drugs becomes a major problem that greatly disrupts service to the public. In addition, the patient data of health insurance participants are not the same between those owned by the central government, local government and hospitals that serve patients. Uncertainty in the implementation of health insurance makes PT Asuransi Kesehatan, which has been appointed to manage the health financing sector, is stopped and replaced by the Social Security Administering Body. Local Government has never been involved in the management of health insurance Government Regulation number 38 year 2004 and Law 32 year 2004 perceived, to be frank, not at best.

The government feels that health affairs remains the authority of the center because it is the center that runs and coordinates the field of health. Poor communication becomes one of the causes of incompatibility between local government and central government. The Health Office feels no role in arranging the Hospital, due to the absence of hand over of authority control. The Health Office has no influence on the medical group, especially the specialist group of doctors. Two different cultures between the views of the Hospital and Office of Health Department colored by public health culture ideology while the Hospital is influenced by the Medical Culture. This was also reflected by two different DGS in the Ministry of Health Hospital under the auspices of the Direc- torate General of Medical Services while the Department of Health under the Directorate General of Community Health. The Health Office conducts health efforts to the community while the Hospital undertakes individual health efforts.

There is a pragmentation of the capabilities resulting from neoliberalism and cultural globalization. Doctors and professions increasingly have a materialistic culture visible from various scientific activities and the congress of the liberal market ideology profession. The absence of standard revenue rules received by doctors becomes a problem when audit is undertaken of doctors who perform services. And Health Insurance does not provide clear signs about the drugs that can be used in the service. There has never been a negotiated story of health insurance for a group of physicians in terms of community service, so that every doctor has his own authority and ordinance in the service. A head of the Hospital cannot control and interfere in medical techniques when a doctor performs a service.

Hospital Leaders have difficulties in finding the shape and culture of hospitals in performing services. The existing organizational culture tends to a complicated bureaucracy that affects every member of the organization. Even the bureaucratic culture has not preferably integrated so that the shape and culture of hospitals in the service of favorable conditions for both hospitals and patients. The Health Department mandated by the law to supervise the Hospital is not ready to become the health sector supervisor. The same position of, different medical dictates in different organizational and cultures has become one of the causes of decentralization not yet implemented. The authority to oversee and be responsible for what should be done by the health service has not become something that can be done due to the distance that occurs between the health office with the Hospital.

The political development of the health sector looks different from other sectors in Indonesia. Seniority and culture of mutual respect look very strong coloring the management of the health sector. Academics do their job well in creating ideology and designing policies in the health sector. Modesty can be felt in the policy logging in regulating health. A striking difference occurs between physicians when performing services in the country. In Indonesia, the doctor is a flashlight in doing the service, the doctor is paid based on the service made, the more patient simply mean the more income the doctor takes. Unlike most doctors abroad, where physicians do not consider a flashlight where the doctor's service is part of duty in the hospital. Therefore, doctors get the amount of salaryis not based on the number of patients served.

Political communication is the process of delivering information about politics from government to society and from society to government. Information is highly important when we speak of modern organizations, because the organization [government] will be able to maintain its power. It is because they do not understand what are the needs of the community, thus emerged dissatisfaction society to the ruler who then lead to the turnover process of goods. It is in a constitutionally or coupled manner. On the other hand, information is also needed by the community to understand the extent to which the government performs its functions, in what manner and how the achievement is desired. Political parties are between government and society. This political party lies between government and society, hence the relationship has strategic position in this regard. In this case, this would be very dependent on the part of political parties are, whether on the part of the government or the opposition, and this will affect the content of the provision of information provided to the community associated with the point of view or value that are fought.

West Java Province as one of the largest provinces in Indonesia has a fairly high commitment to the implementation of health services for the community. West Java Province will develop seven regional hospitals as referral hospitals. This is done as an effort of equitable health care for the people of West Java. There are seven regional hospitals that will be developed as regional referral hospitals. Among these are Cibinong Hospital, Hospital of SyamsuddinSukabumi, Gunung Jati Hospital in Cirebon, Tasikmalaya Hospital, Hospital Al-Ihsan Bandung, Ciba- 
batCimahi Hospital, and theKarawang Hospital. In this study, researchers uses qualitative method with Case Study approach. Researchers think that this method is highly suited interpret the phenomena in health political communication research in the post applicationof PP No. 18 year 2016. As explained by [7]as thick description, the processes are complex and influence in certain contexts. The ability to provide rich portraits in this way is a key benefit of case studies. Your research reader should be made to feel as if they were there with you in your research, see what you see, summarize what you have concluded. [8]

The case study approach, according to the researchers, are possible way to describe and explore the phenomenon seen in health political communication after the adoption of PP no 18 year 2016 Raco explained this case study can help researchers to conduct indepth study of individuals, groups, programs, organization, cultural, religious, regional or even state. Understanding of special cases that occurred in the past will help individuals, communities to understand and solve the problems they are facing. [9]

\section{Literature Review}

\section{1. Health Political Communication}

Speaking of political communication is not as easy as talking about political movements, there are two disciplines that talk about communication and politics. If communication is understood as a process then the communication in question is a communication done either way or done dynamically. David K states that something is defined as a process, which means the elements that support it move actively, dynamically and not statically In the context of communication means there has been a process of sending messages made by communicators to the communicant then get the reciprocity or appropriate response desired by the sender of the message. In the interpersonal communication activities, when in mass communication then there has been collecting, processing and dissemination of news messages from publishers through mass media to a crowd or a wide audience desired by communicators.

In 2004, the election of MPs, presidents and vice-presidents in Indonesia, the system was no longer identical with the election held during the Soeharto era, but the people already elect the president and the vice president directly like the United States which is widely known as the champion of democracy. The direct election system does not merely elects the president and the vice president but also directly elect the governor and deputy governor, and the regent and / vice regent, mayor and deputy mayor accordingly. [10]

The electoral system as mentioned above also influences into al aspects of the people's life. The central government delegates some of its power to the local government, so that local governments have more authority in determining the regional apparatus. The current regional autonomy is a manifestation of the collapse of the centralized government system which attracts almost all central government authority. Since the enactment of Law no. 5 year 1974 concerning the Principles Government in the Region then the broadest autonomy as set forth in Law No. 18 year 1965 on the Principles of Regional Government and TAP MPRS No. XXI / MPRS / 1966 are reversed into what the law calls "the real and responsible implementation of regional autonomy". This reversal is done under the pretext that the broadest autonomy is no longer compatible with the principle of the state order of the Republic of Indonesia and must therefore be changed. A real regional autonomy is responsible for changing the authority to regulate and take care of itself becomes an autonomy that carries out the mandate and central power in the region. [11]

Post-New Order reflects new political logic and mechanisms for society [and elites] at all levels of politics. 'New politics' describes resistance to 'old politics' which is autocratic, repressive, and centralized. The interpretation of 'new politics' is also understood as the birth of polycentrism over the consequences of decentralization. Polycentrism is defined simply as the collective strug- gle of society or region to reject the old idea [or ruler] which is considered to have weakened their identity and power. [12]

This is considerably affects the management of regional apparatus organizations as well as units of Work Device under the target area. Communication becomes one of the tools for exchanging messages and power sharing in the region. Political communication can be interpreted as a form of government effort and its regional apparatus carry out the task to organize and serve the community. Politics is always interpreted as cruel and dirty in society, politics is like a blade that has a variety of good and bad sides. Such as knives can be used to slice food or kill humans.

Goran Hadebro [1982] a Swedish professor of communication develops more functional media purpose in his book Communication and Social Change in Developing Nations. In his book he developed media function into 12 functions namely:

Create a climate of change by introducing new values to change attitudes and behavior of modernism

Teach new skills skills to the community

Serve as multiplayer effect [science multiplayer] by disseminating through communication media

Creating energy efficiency and cost to mobility of a person through information they receive from the media without the need to visit the place where informed

Increase one's aspiration with information read, heard and seen.

Growing participation in decision-making on matters of public interest

Assist the public in discovering the new value and harmony of a particular situation.

Enhance the sense of nationality through the presentation of information that inspires a sense of care for the fate of the nation and state

Increase one's political activity to take part in public policy determination.

Change the power structure in society through the unification of attitudes to subdue tyranny.

Become a means of learning through the exchange of ideas and experiences of community members without knowing the place and distance

Support the implementation of programs of economic, social and security development programs in order to increase the welfare of the citizens. [10]

The changing political climate also affected the management of local hospitals that have been owned by the local government. The hospital has unique management because there are various professions such as doctors, nurses, pharmacy staff, financial administration and other professions. Certainly it is not an easy matter for a hospital director to manage and synergize with many professions in the hospital.

Political turbulence is also felt by the manager of a local hospital with the emergence of government regulation number 18 of 2016. Hospital is one of the services that in carrying out its activities should not be separated from the development of science and technology. Both of these things increase the awareness and demands of society to health services better. It also causes the value of society to change to health services that are more qualified. This shift is a challenge for the hospital faced with the changing business environment. [13]

\section{Methodology/Materials}

The research paradigm in this study using naturalistic paradigms within the scope of the sociocultural tradition, researchers naturally examine the existence of social and cultural research subjects, where communication is focused on social reality. In the book Sociology of Communication [14]. One approach in science is the social sciences. Although the social science approach is generally an attempt to use the exact sciences approach in view of society as referred to by August Comte introducing sociology as a science that discusses social life borrowed from physics. In attempting to observe and interpret patterns of human behavior, the roots of social science make man an object of study to observe. If behav- 
ioral patterns are in fact present, then observation should be as objective as possible, in other words, social scientists such as natural scientists must establish a consensus on what is observed accurately which will be explained or interpreted. [15]

SuwardiEndraswara in his work entitled Method, Theory, Engineering, Cultural Research, Understanding Robert Friedrichs, paradigm as a fundamental view of a discipline on what the subject matter should be studied [a fundamental image a dicipline has of its Subject matter]. [16]Researcher who is observing at the phenomenon of health political communication after the application of Government Regulation No. 18 of 2016 trying to think thoroughly, looking for a frame in accordance with the study of communication science is realistic. Researchers are in a neutra position, and look for a complete picture of the process of communication. The paradigm is a loose collection of logically shared assumptions, concepts, or propositions that direct the way of thinking and the way of research. Theoretical orientation or perspective is a way of looking at the world, what people assume about something important, and what makes the world work. The paradigm becomes a mind frame in which contains the concept and map of the study thoroughly. [16]

Methods are the perspective and principles of thinking about the phenomena studied, the approach used, the scientific procedures [methods] followed, including in collecting data, data analysis, and conclusions. Bogdan and Taylor [1975: 1] briefly state the methodology as the process, principle, and procedure of how we perceive problems and seek answers]. [17]

Research that is conducted by researchers is a naturalistic research. According to [18] Qualitative research or also called naturalistic research evolved along with knowledge about the flow of humanism as the root of explanation of human behavior. [19], citing [Strauss and Corbin, 1997: 1] Qualitative Research is a type of research that results in discoveries that can not be achieved by using statistical procedures or by other means of quantification. In qualitative research, there are four subjective assumptions about scientific truth or reality, as follows: [1] Nominalism, scientific truth is the result of a construction that is given a partiality by the individual, including the researcher; [2] Antipositivism, Scientific truth can only be understood from the perspective of the individual [3] Voluntarism, Man is assumed to be an autonomous being. In full and have "free will", they actively and creatively live the reality; [4] Ideographic, qualitative research seeks to understand and explain reality. They try to assemble and arrange patterns to discover something new or theory through the induction ofscientific process[inductive thinking method]. Qualitative research is "theoretical gathering" by assembling and developing patterns of individual social action. [18]

Research method used by researchers is qualitative research method. Researchers view that this research as interactive, and minimize the level of subjectivity. The research will be conducted by the researcher is health political communication in the post application of PP no 18 year 2016.

Qualitative Research by Yin [2011] in [18][1] attempts to study the meaning of living people in real-world conditions and situations; [2] Representing the views and perspectives of the community in research; Society is not an object of observation, but they provide a picture of the true reality of facts to scientific truth; [3] includes the contextual conditions in which members of the living community [4] contribute to the development of insights into existing or new concepts that can help to explain human social behavior, and [5] strive to use multiple sources of data rather than relying on one source. Qualitative research is known as a study that develops participatory field approaches.

In this study, researchers used qualitative method with Case Study approach. Researchers think that this method is very appropriate that can describe the phenomenon in the study of health political communication in the post-application PP No. 18 year 2016. As described by [7] Thick description, about the complex processes and their influence in a particular context. The ability to provide rich portraits in this way is a key benefit of case studies. Your research reader should be made to feel as if they were there with you in your research, see what you see, and summarize what you have concluded. [8]

According to Patton the process of preparing the case study takes place in three stages. The first stage is the collection of raw data about individuals, organizations, programs, places of occurrencein the basis of writing case studies. The second step is to compile or arrange cases that have been obtained through compacting, summarizing data that is still in the form of raw data, classifying, editing and inserting it in one file that can be set [manageable] and accessible. The third step is writing the final report of case study in the form of narration. [9]

In qualitative research, researchers naturally view the problem in the context of the study, the researcher plunged into the events and conditions that occur in the context of research. Researchers are directly in the field on various sides of events that occur when the observation process takes place. According to Bajari Qualitative Research demands a high level of extinction. An intensive researcher goes into a community to get a complete picture of situation or experience. Pretending becomes the "ultimate weapon" to "hide" identity as a researcher. This is done to get the typical data, not intervened feeling is being researched. As well as attempting to construct opinions and behavior descriptions of key informant. This effort can only succeed if the researcher establishes a relationship that can be accepted by the informant.

According to Stake [1995], Case Studies is a research strategy in which researchers carefully investigate a program, event, activity, process, or group of individuals. Cases are limited by time of activity; with researchers collect complete information using various data collection procedures based on the time specified. [20]

The case study approach, according to the researcher, is a possible way to describe and explore the phenomenon seen in health political communication after the adoption of goverment regulations no 18 of 2016. Raco explained This case study can help researchers to conduct in-depth study of individuals, groups, programs, organization, cultural, religious, regional or even State. Understanding of special cases that occurred in the past will help individuals, communities and communities to understand and address the issues at hand or to be faced [9]

According to [21] provides more technical limitations with an emphasis on its characteristics. Ary, Jacobs, and Razavieh [1985] explained that in case studies the researcher should try to test the unit or individual in depth. The researchers tried to find all the variables that are important in the study. Based on these restrictions it is understandable that case study is partial include; [1] the target of his research may be human, event, background, and document; [2] those goals are examined in depth as a totality according to their respective backgrounds or contexts in order to understand the various links that exist between the variables.

\section{Results and findings}

Indonesia is widely known as the third largest democracy in the world, hence in implementing its government in accordance with the will of society. All people have the same rights and wills in the eyes of democratic law, the authority of the people is channeled through the electoral system where the people are free to choose their representatives to run the government in Indonesia. The fall of the Soeharto regime became the starting point of the direct electoral system in Indonesia.

The domino effect of politics in Indonesia touched the region, the Government Regulation No. 18 year 2016 is the latest regulation regarding regional governance, Government Regulation is derived from Law number 23 year 2014. Article 43 in Government Regulation Number 18 year 2016 mentioned that the Regional Hospital as a Functional organization unit that works professionally.

The amendment of Government Regulation number 182016 years begins with the issuance of Law number 23 year 2014 regarding regional instrument organization to replace Law No. 32 year 2014. In the law is submitted that the regional apparatus consists of the Regional Secretary, Secretary of DPRD, Inspectorate, and sub-districts in the law Regional Hospital which was 
originally referred to the regional technical institutions shifted into Government Regulation number 18 year 2016. In the regulation mentioned that the Regional Hospital is under the Health Service, Regional hospital must perform its function to serve the society professionally.

Hospital management has experienced turbulence of power as conveyed by chairman of Indonesian Doctors Association dr. DwiSusilo in an interview, within the period of 2016 there has been a change in hospital regulations related to handling BPJS 5 times, this is very confusing and certainly influence hospital management.

The publication of new rules on hospital management states that the previous hospital status is a regional technical institution turned into a limited service unit under the service health. Referring to the rule, the hospital management is no longer structural officials who participate in the management of the hospital. The hospital is completely run by the hospital's functional personnel at the head by a Director of the Hospital who is a functional person who is assigned additional duties as Director.

Decentralization is the effect of democratization. The goal is for good governance through political grassroots. [22] The health office is considered as the coordinator in the implementation of health services to the community, the health office has the duties and responsibilities that interconnected with the hospital. During this position, the health department head parallel to the director of the hospital, in preparing of a strategic plan implementation because both have the same level so that both must synergize in carrying out the service activities to the community.

Government Regulation number 18 year 2016 on article 43 states that the director is a functional doctor who is given additional to become director in hospital, so in practice later a director should prioritize service to the community before carrying out additional duties to become director. This will certainly difficult for the organization of the hospital, given the duties of a director is not simple, the obligation to accreditation of every hospital that perform health care services, making the hospital as a good place for the development of education is certainly not a task that can be performed supplementary, as explained by dr. Asep Hidayat Lukman MM Director of RSUD Kabupaten Karawang.

The position of the director of the hospital is appointed and dismissed by the decree of the Chief Medical Officer and is not a primary duty for the functional physician in the hospital. Human resources in the organization are crucial aspect that determines the effectiveness of an organization. Therefore organizations always need to invest by carrying out human resource functions starting from recruitment, selection to maintain human resources. But the phenomenon is often occurred when a company's performance has been directly or indirectly damaged by various employee behaviors. One form of employee behavior is the intention to leave his job. Outward intent [turnover intentions] can be defined as the movement of labor out of the organization. Turnover may include resignation, transfer of organizational unit, dismissal, or death of an organization member [23]

In Government Regulation number 18 year 2016 article 43 mentioned that the director is only an additional task given to the director through the Head of Health Department Decree. It structurally changed the status of hospitals that initially in the form of regional technical institutions into Limited Service Unit of the Region will greatly affect the way the organization in the hospital Take for example the provision of tetanus medicine, tetanusshaped injection drug for newborn babies usually only found in the Hospital, if at the time, the hospital in the form of regional technical institutions when the drug is empty then the Director of the Hospital can immediately order to the relevant field to immediately do the procurement of drugs even Home Pain can buy directly if the drug is very important and includes a class of drugs that are needed by the service. If the hospital becomes a Limited Service Unit, then the Hospital first reports the condition to the Health Department and wait for the delivery of drugs from the Health Office. Procurement of goods and services performed in the Health Office has a different procedure with the Hospital
Health Department is a Regional Device Organization that all kinds of procurement must be planned and cannot suddenly done at that time due to the Regional Device Organization which has many Limited Service Unit. It must see and check whether other limited service unit in this case comunity health center have completed the financial and administrative report due to the procurement for the hospital cannot be done separately. Thus explanation Director of RSUD Karawangdr. AsepHidayatLukman MM

According to Mobley [1977] on Judge [1993], the desire to end task or leave the organization negatively related to job satisfaction. Perceived job satisfaction can affect a person's thinking toexit. Evaluation on various works, will eventually realize the occurrence turn ove because individuals who opt out of the organization will expect more satisfying results elsewhere. [23]The Director as an additional assignment will be one reason to override his duties as director and prioritize service to the community.

After the issuance of government regulation number 28 year 2016 article 43 mentioned that the Director of Hospital is a doctor who still required to do service as main duty and Director only as additional task. This will certainly influential on the office of the health service, because the Presidential Regulation enlarges the scope of power of the head of health service. Appointment of the Director no longer has to wait for the Decree from the current head of all these responsibilities to be in the position of the Chief Medical Officer where a head of the Health Service is not mentioned should be a doctor, but anyone who has a health background. This will certainly affect the psychological of the Director, because as we completely understand the position of Civil Servant is the most idolized position. According to health ministry regulations and policies of BPJS that every hospital should have been accredited 2012 and become Education Hospital. Hospital Accreditation 2012 version is no longer talking about the examination of documents that have been going on. Accreditation 2012 aims to allow patients to know what the health workers do during their being. The Director of the Hospital along with the ranks of structural officials is required to ensure that any action taken is well received by the customer in this case the hospital patient.

\section{Conclusion}

The post-decline of government regulation number 18 year 2016 where mentioned that the hospital turned into a limited service unit under the health service. Article 43 in the government regulation states that the hospital still be chaired by a director. The Director is a functional physician who gets an additional duty to become a Director. In its implementation, the Director should prioritize his functional tasks as a public servant, after which only undertake additional duties as director. The duties of the hospital director include preparing for hospital accreditation, providing services to the public and making hospitals a good place for educational purposes for doctors and other health workers, certainly not a task that can be carried out in additional task settings.

The law number 32 of 2014 on regional autonomy is the beginning of the loss of hospital status as a regional technical institution so that the hospital must integrate with the health service and become a limited service unit. After the decline of the law number 32 of 2014 was born the government regulation number 18 year 2016 about the regional tools in the government regulation mentioned that the hospital as a professional institution led by a director who is a doctor or dentist who was given an additional task by the head of the health service for Leading the hospital. In practice the hospital is run using a special rule that is the financial management pattern of the regional public service agency which states that one of the members of the hospital supervisory board is the head of the health department In organizational communication there is little ambiguity when the supervisory board is the institution in charge of running the hospital. It is necessary to study other studies to see how far the implementation of government regulation number 18 of 2016 is executed in accordance with the provisions. 


\section{References}

[1] Rahardja P, Manurung M. Teori Ekonomi Makro: Suatu Pengantar. Lembaga Penerbit Fakultas Ekonomi Universitas Indonesia Jakarta. 2004.

[2] Bass BM, Stogdill RM. Bass \& Stogdill's handbook of leadership Theory, research, and managerial applications: Simon and Schuster; 1990.

[3] Schein EH. Organizational culture and leadership: John Wiley \& Sons; 2010.

[4] Porter ME. Clusters and the new economics of competition: Harvard Business Review Boston; 1998.

[5] Trisnantoro L. Pelaksanaan Desentralisasi Kesehatan di Indonesia 2000-2007, Mengkaji Pengalaman dan Skenario Masa Depan. BPFE, Yogyakarta. 2009.

[6] Walshe K, Rundall TG. Evidence-based management: from theory to practice in health care. The Milbank Quarterly. 2001;79[3]:42957.

[7] Geertz C. Works and lives: The anthropologist as author: Stanford University Press; 1988.

[8] Daymon C, Holloway I. Qualitative research methods in public relations and marketing communications: Routledge; 2010.

[9] Raco JR. Metode penelitian kualitatif: jenis, karakteristik dan keunggulannya. Jakarta: Grasindo. 2010.

[10] Cangara H. Komunikasi politik: konsep, teori, dan strategi: Rajawali Pers; 2009.

[11] Pranadji T. Otonomi Daerah dan Daya Saing Agribisnis: Pelajaran dari Provinsi Lampung. Analisis Kebijakan Pertanian. 2017;1 [2].

[12] Agustino L, Yusoff MA. Politik Lokal di Indonesia: Dari Otokratik ke Reformasi Politik. Jurnal Ilmu Politik Edisi. 2010;21.

[13] Gunawan K, Djati SP. Kualitas Layanan dan Loyalitas Pasien [Studi pada Rumah Sakit Umum Swasta di Kota Singaraja-Bali]. Jurnal Manajemen dan Kewirausahaan [Journal of Management and Entrepreneurship]. 2011;13[1]:32-9.

[14] Bungin B. Sosiologi Komunikasi: teori, paradigma dan diskursus teknologi komunikasi di masyarakat. 2006.

[15] Bungin B. Penelitian Kualitatif: Komunikasi, Ekonomi, Kebijakan Publik dan Ilmu Sosial Lainnya. 2007.

[16] Endraswara S. Metodologi penelitian sastra: Niaga Swadaya; 2008

[17] Pawito. Komunikasi politik: media massa dan kampanye pemilihan Jalasutra; 2009.

[18] Bajari A. Anak jalanan: dinamika komunikasi dan perilaku sosial anak menyimpang2012.

[19] Sukidin B. Metode Penelitian Kualitatif Perspektif Mikro. Insan Cendekia Surabaya. 2002.

[20] Creswell JW. Qualitative inquiry and research design: Choosing among five approaches: Sage publications; 2012.

[21] Yin RK. Case study research: Design and methods: Sage publications; 2013.

[22] Haris S. Desentralisasi dan otonomi daerah: desentralisasi, demokratisasi \& akuntabilitas pemerintahan daerah: Yayasan Obor Indonesia; 2005

[23] Andini R. Analisis Pengaruh Kepuasan Gaji, Kepuasan Kerja, Komitmen Organisasional Terhadap Turnover Intention [Studi Kasus Pada Rumah Sakit Roemani Muhammadiyah Semarang]: Program Pasca Sarjana Universitas Diponegoro; 2006. 